\title{
STEM-INTEGRATED PROJECT-BASED LEARNING (PjBL) MODEL AND \\ LECTURE WITH EXPERIMENTS LEARNING MODEL: WHAT IS THE SCIENTIFIC LITERACY SKILLS OF ELEMENTARY TEACHER EDUCATION STUDENTS IN THESE LEARNING MODELS?
}

\section{Duhita Savira Wardani ${ }^{1}$, Medita Ayu Wulandari ${ }^{2}$, Faridillah Fahmi Nurfurqon ${ }^{3}$, Dian Kurniawati ${ }^{4}$}

\author{
IKIP Siliwangi, Indonesia ${ }^{1,2,3}$, The University of Sheffield, United Kingdom ${ }^{4}$ \\ E-mail: duhita@ikipsiliwangi.ac.id ${ }^{1}$, medita@ikipsiliwangi.ac.id², \\ faridillah@ikipsiliwangi.ac.id ${ }^{3}$, dkurniawatid@gmail.com ${ }^{4}$
}

DOI: 10.14421/al-bidayah.v13i1.634

\begin{abstract}
This study aimed to determine the difference in students' scientific literacy skills between students who apply the PjBL model integrated STEM-assisted science literacy modules and students who apply lecture learning accompanied by experiments. The subjects of this study were 60 Elementary Teacher Education students who were divided into two classes at IKIP Siliwangi Bandung. This study used a comparative research method with a quantitative approach. The data collection method used was the scientific literacy skills test method. The test instrument in this study measured three scientific literacy competencies, namely the ability to explain scientific phenomena, evaluate and design scientific investigations, and interpret scientific data and evidence. The data were analyzed using descriptive analysis techniques and an Independent Sample T-Test. This study's results showed that the average scientific literacy ability of students who received the STEM-integrated PjBL model in this study was 83 . The T-test of average students' scientific literacy ability showed that the PjBL model integrated STEM-assisted modules affected students' scientific literacy skills better than lecture learning accompanied by experiments. The recommendation of this study is further research to modify the STEM-integrated PjBL model assisted by this module to be more effective in improving students' ability to interpret scientific data and evidence.
\end{abstract}

Keywords: elementary education students; project-based learning; science literacy; STEM

\section{INTRODUCTION}

Science plays an essential role in creating reliable and quality young people in facing the challenges of the globalization era. ${ }^{1}$ Science helps humans to develop mindsets, become more rational, creative, analytical, critical, and develop the ability to conduct research and the ability to systematically solve problems and make decisions using information based on scientific evidence. ${ }^{2}$ Therefore in science education, students need to be equipped with scientific literacy skills to develop in society, think critically and

\footnotetext{
${ }^{1}$ Desi Novita Anggun Sari, Ani Rusilowati, and Murbangun Nuswowati, "Pengaruh Pembelajaran Berbasis Proyek Terhadap Kemampuan Literasi Sains Siswa," PSEJ (Pancasakti Science Education Journal) 2, no. 2 (2017): 114, https://doi.org/10.24905/psej.v2i2.741.

2 Lertporn Udompong and Suwimon Wongwanich, "Diagnosis of the Scientific Literacy Characteristics of Primary Students," Procedia - Social and Behavioral Sciences, 2014, https://doi.org/10.1016/j.sbspro.2014.01.1079.
} 
creatively to plan problem solving, and have deep knowledge and understanding to be applied in their lives.

According to PISA, science literacy is defined as an individual's scientific knowledge and use of that knowledge to identify questions, acquire new knowledge, explain scientific phenomena, and draw evidence-based conclusions about sciencerelated issues. ${ }^{3,4}$ Based on this definition, scientific literacy consists of three aspects, namely the ability to be able to identify what is included in scientific facts, the ability to use appropriate investigation methods to obtain the scientific evidence needed, and the ability to analyze and interpret this evidences so that meaningful conclusions can be obtained. Why is it essential in $21^{\text {st }}$-century education for scientific literacy to be integrated into the learning process? The purpose of science education is to increase students' competence to meet their needs in various situations, including facing life challenges in the global era ${ }^{5}$. With scientific literacy, students will learn further and live in a modern society currently heavily influenced by developments in science and technology. ${ }^{6,7}$ In addition, with scientific literacy, students are expected to have sensitivity in solving global problems such as environmental, health, and economic problems. The urgency of this literacy is because understanding science offers a solution to these problems.

On the other hand, the study results of the PISA of Indonesian students still cannot reach the overall average score. Indonesia's scientific literacy achievements at the 2018 PISA, which was attended by 78 countries, ranked 72 . The average score of Indonesian students on scientific literacy is 396 below the average PISA score, $489 .^{8}$ The lack of scientific literacy in Indonesia reflects that students in Indonesia are primarily unable to analyze and apply the concept to solve a problem. ${ }^{9}$ Students tend to memorize the concept

${ }^{3}$ OECD, "PISA 2015 Draft Scince Framework March 2013,” 2013.

${ }^{4}$ Y. Ardiyanti, S. Suyanto, and I. G.P. Suryadarma, "The Role of Students Science Literacy in Indonesia," in Journal of Physics: Conference Series, 2019, https://doi.org/10.1088/17426596/1321/3/032085.

5 Punia Turiman et al., "Fostering the 21st Century Skills through Scientific Literacy and Science Process Skills," Procedia - Social and Behavioral Sciences, 2012, https://doi.org/10.1016/j.sbspro.2012.09.253.

6 Yuyu Yuliati, "Literasi Sains Dalam Pembelajaran IPA," Jurnal Cakrawala Pendas 3, no. 2 (2017): 21-28, https://doi.org/10.31949/jcp.v3i2.592.

${ }^{7}$ Jack Holbrook and Miia Rannikmae, "The Meaning of Scientific Literacy," International Journal of Environmental and Science Education 4, no. 3 (July 2009): 275-88, https://eric.ed.gov/?id=ej884397.

8 OECD, "PISA 2018 Results in Focus.Https://Www.Oecd.Org/Pisa/Pisa-2018-Results-inFocus.Pdf," 2018

9 Jufrida Jufrida et al., "Scientific Literacy and Science Learning Achievement at Junior High 
but are still lacking in their use of knowledge. ${ }^{10}$ The study conducted by Jufrida ${ }^{11}$ in Jambi supported this statement. Jufrida founds that the understanding of the science concept of students is still low, students struggle to solve the problem of applying mathematical equations, students are not accustomed to solving problems related to science, students have never received training to solve scientific literacy problems, students still remember the materials submitted by the teacher. Students rarely study independently at home. The low scientific literacy of Indonesian students may be affected by many factors, including the learning model used by teachers and the textbooks used by students. ${ }^{12}$ The learning model is an essential part of carrying out the learning process. One learning model can build student learning experiences based on the products produced in the Project-Based Learning (PjBL) model. ${ }^{13}$

The application of $\mathrm{PjBL}$ in science learning from research results can improve cognitive learning outcomes ${ }^{14}$, scientific literacy ${ }^{15}$, shape attitudes and behaviors that care for the environment ${ }^{16}$, science process skills ${ }^{17}$, and effective learning. ${ }^{18} \mathrm{PjBL}$ is considered appropriate in interdisciplinary learning because it naturally involves many different academic skills such as writing, reading, and mathematics and is suitable in

School," International Journal of Evaluation and Research in Education, 2019, https://doi.org/10.11591/ijere.v8i4.20312.

10 A. D. Paramita, A. Rusilowati Sugianto, "Pengembangan Bahan Ajar Berbasis Literasi Sains Materi Suhu Dan Kalor," Phenomenon: Jurnal Pendidikan MIPA, 2017, https://doi.org/10.21580/phen.2017.7.1.1495.

11 Jufrida et al., "Scientific Literacy and Science Learning Achievement at Junior High School."

12 Feni Kurnia, . Zulherman, and Apit Fathurohman, "Analisis Bahan Ajar Fisika Sma Kelas Xi Di Kecamatan Indralaya Utara Berdasarkan Kategori Literasi Sains," Jurnal Inovasi Dan Pembelajaran Fisika, 2014, https://doi.org/10.36706/jipf.v1i1.1263.

13 Jaka Afriana, Anna Permanasari, and Any Fitriani, "Penerapan Project Based Learning Terintegrasi STEM Untuk Meningkatkan Literasi Sains Siswa Ditinjau Dari Gender," Jurnal Inovasi Pendidikan IPA 2, no. 2 (2016): 202, https://doi.org/10.21831/jipi.v2i2.8561.

${ }^{14}$ Medine Baran and Abdulkadir Maskan, "The Effect Of Project-Based Learning On Pre-Service Physics Teachers Electrostatic Achievements," Cypriot Journal of Educational Sciences 5, no. 4 (2011): 243-57, https://archives.un-pub.eu/index.php/cjes/article/viewArticle/117.

${ }^{15}$ Afriana, Permanasari, and Fitriani, "Penerapan Project Based Learning Terintegrasi STEM Untuk Meningkatkan Literasi Sains Siswa Ditinjau Dari Gender.” (2016). Penerapan project based learning terintegrasi STEM untuk meningkatkan literasi sains siswa ditinjau dari gender. Jurnal Inovasi Pendidikan IPA, 2(2), 202. https://doi.org/10.21831/jipi.v2i2.8561

${ }^{16}$ Ahmet Kılınç, "Can Project-Based Learning Close The Gap? Turkish Student Teachers and Proenvironmental Behaviours," 2010, http://openaccess.ahievran.edu.tr/xmlui/handle/20.500.12513/181.

${ }^{17}$ Dilek Zeren Özer and Muhlis Özkan, "Proje Tabanlı Öğretimin Fen Bilgisi Öğretmen Adaylarının Bilimsel Süreç Becerileri Üzerine Etkisi," Journal of Turkish Science Education 9, no. 3 (September 15, 2012): 119-30, http://www.tused.org/index.php/tused/article/view/443.

${ }^{18}$ Kristin Cook, Gayle Buck, and Meredith Park Rogers, "Preparing Biology Teachers To Teach Evolution In A Project-Based Approach," Science Educator 21, no. 2 (2012): 18-30, https://www.nsela.org/assets/Preparing\%20Biology\%20Teachers\%20to\%20Teach\%20Evolution\%20in\% 20a\%20Project-Based\%20Approach.pdf. 
building conceptual understanding through assimilation of different subjects ${ }^{19}$ so that $\mathrm{PjBL}$ is expected to build student scientific literacy.

Apart from PjBL, current learning needs to keep up with the times in the era of globalization, one of which is by integrating Science, Technology, Engineering, and Mathematics (STEM). The relationship between science and technology and other sciences cannot be separated in science learning. STEM is a discipline that is closely related to one another. Science requires mathematics as a tool in processing data, while technology and engineering are applications of science. The expectation from implementing the STEM approach to learning is to produce meaningful learning for students through the systematic integration of knowledge, concepts, and skills. Some of the STEM approach benefits make students solve problems better, become innovators, inventors, independent, logical thinkers, and help them acquire technological literacy. ${ }^{20}$ Therefore, implementing STEM project-based learning in learning is expected to positively influence students' scientific literacy, creativity, and learning outcomes. ${ }^{21}$

Several studies on PjBL and scientific literacy have been conducted, including Morrison, ${ }^{22}$ which examines the influence of $\mathrm{PjBL}$ on student science success. Furthermore, Susilawati \& Agustinasari ${ }^{23}$, and Gofur ${ }^{24}$ examine the influence of PjBL on student process skills. Wardani ${ }^{25}$ did a study to determine the improvement of students' writing skills through PjBL. The research of Panasan ${ }^{26}$ also examined student

19 Robert M. Capraro, Mary Margaret Capraro, and James R. Morgan, STEM Project-Based Learning an Integrated Science, Technology, Engineering, and Mathematics (STEM) Approach, STEM Project-Based Learning an Integrated Science, Technology, Engineering, and Mathematics (STEM) Approach, 2013, https://doi.org/10.1007/978-94-6209-143-6.

${ }^{20}$ Micah Stohlmann, Tamara Moore, and Gillian Roehrig, "Considerations for Teaching Integrated STEM Education,” Journal of Pre-College Engineering Education Research, 2012, https://doi.org/10.5703/1288284314653.

21 Lutfi Lutfi, Andi Asmawati Azis, and Ismail Ismail, "Pengaruh Project Based Learning Terintegrasi Stem Terhadap Literasi Sains, Kreativitas dan Hasil Belajar Peserta Didik," Seminar Nasional Biologi, no. 0 (October 17, 2018), https://ojs.unm.ac.id/semnasbio/article/view/6984.

${ }^{22}$ N. Remziye Ergül and Elif Keskin Kargın, "The Effect of Project Based Learning on Students' Science Success," Procedia - Social and Behavioral Sciences 136 (2014): 537-41, https://doi.org/10.1016/j.sbspro.2014.05.371.

${ }^{23}$ Endang Susilawati and Agustinasari, "Implementasi Project Based Learning Berbasis Potensi Lokal Untuk Meningkatkan Keterampilan Proses Sains Mahasiswa Pendidikan Fisika," Jurnal Pendidikan MIPA 7, no. 1 (June 30, 2017): 43-47, http://www.ejournal.tsb.ac.id/index.php/jpm/article/view/19.

${ }^{24}$ Nuril Maghfiroh, Herawati Susilo, and Abdul Gofur, "Pengaruh Project Based Learning Terhadap Keterampilan Proses Sains Siswa Kelas X SMA Negeri Sidoarjo,” Jurnal Pendidikan: Teori, Penelitian, dan Pengembangan 1, no. 8 (August 1, 2016): 1588-93, https://doi.org/10.17977/jp.v1i8.6673.

${ }^{25}$ Duhita Savira Wardani et al., "Creating Props: Improving Writing Skills of Teaching Materials of Elementary Teacher Education Students through Project-Based Learning Model," Mimbar Sekolah Dasar 7, no. 2 (2020): 216-34, https://doi.org/10.17509/mimbar-sd.v7i2.26334.

26 Mookdaporn Panasan, Prasart Nuangchalerm, and Amphoe Muang, "Learning Outcomes of 
learning outcomes from the application of PjBL and inquiry. In addition, a study conducted from the teacher's side has also been carried out by Toolin ${ }^{27}$, who examined the balance between innovation and standards in the application of PjBL in science learning. Thus, research that builds scientific literacy by implementing STEM-integrated $\mathrm{PjBL}$ is still not widely done in Indonesia from some of these studies.

Therefore, by raising these problems, this study will explore and describe the students' scientific literacy skills in learning using the STEM integrated PjBL model and using lecture learning with experiments. With this in mind, this study aimed to find out the difference in scientific literacy skills between the two classes.

\section{RESEARCH METHODS}

This research used a comparative method with a quantitative approach. IKIP Siliwangi Bandung becomes place this research. We used the comparative method to determine the difference in scientific literacy skills between class A1 which received STEM integrated Project Based Learning (PjBL) assisted by the science concept modules, and class A2, which received lecture learning accompanied by experiments and used teaching materials commonly used in lectures. The stages in the research were started by formulating problems, looking for theories, finding theoretical answers, collecting data, managing data, and drawing conclusions. The subjects in this study were 60 students of Elementary Teacher Education of 2019 academic year with purposive sample technique, while the object was the student's scientific literacy ability. The data collection method used was the scientific literacy skills test method. The test instrument in this study measured three scientific literacy competencies, namely the ability to explain scientific phenomena, evaluate and design scientific investigations, and interpret scientific data and evidence. Table 1 shows the grid of scientific literacy questions.

Project-Based and Inquiry-Based Learning Activities Department of Curriculum and Instruction , Faculty of Education, Mahasarakham University , Mahasarakham 44000 Thailand," Journal of Social Sciences 6, no. 2 (2010): 252-55, https://files.eric.ed.gov/fulltext/ED509723.pdf.

${ }^{27}$ Regina E. Toolin, "Striking a Balance Between Innovation and Standards: A Study of Teachers Implementing Project-Based Approaches to Teaching Science," Journal of Science Education and Technology 13, no. 2 (2004): 179-87, https://doi.org/10.1023/b:jost.0000031257.37930.89. 
Table 1

Grid of Scientific Literacy Questions

\begin{tabular}{|c|c|c|}
\hline No. & Indicators & Question number \\
\hline 1 & $\begin{array}{l}\text { Explain scientific phenomena } \\
\text { a. remembering and applying appropriate } \\
\text { knowledge } \\
\text { b. identifying, using, and producing a } \\
\text { transparent and representative model } \\
\text { c. making and justifying correct predictions } \\
\text { d. providing a clear hypothesis; and } \\
\text { e. explaining the potential implications of } \\
\text { applying scientific knowledge to society. }\end{array}$ & $\begin{array}{l}3 \\
4 \\
5\end{array}$ \\
\hline 2 & $\begin{array}{l}\text { Evaluate and design scientific investigations } \\
\text { a. identifying questions for further exploration } \\
\text { through scientific investigation; } \\
\text { b. distinguishing questions that can be } \\
\text { investigated scientifically; } \\
\text { c. proposing ways of exploring a given question } \\
\text { scientifically; } \\
\text { d. evaluating how to explore questions } \\
\text { scientifically; and } \\
\text { e. explaining and evaluating like a scientist } \\
\text { ensuring the reliability and objectivity of the } \\
\text { data. }\end{array}$ & $\begin{array}{l}6 \\
7 \\
8 \\
9\end{array}$ \\
\hline 3 & $\begin{array}{l}\text { Interpret scientific data and evidence I } \\
\text { a. transforming data from one form of } \\
\text { representation to another; } \\
\text { b. analyzing and interpret data and drawing } \\
\text { appropriate conclusions; } \\
\text { c. identifying assumptions, evidence, and } \\
\text { reasoning with related science; } \\
\text { d. distinguishing between arguments based on } \\
\text { scientific evidence, theory, and other } \\
\text { considerations; and } \\
\text { e. evaluating scientific arguments and evidence } \\
\text { from different sources }\end{array}$ & $\begin{array}{l}11 \\
12 \\
13\end{array}$ \\
\hline
\end{tabular}

The scientific literacy test used consisted of 15 multiple-choice items with openended reasons, namely five questions representing the ability to explain scientific phenomena, five questions representing the ability to evaluate and design scientific investigations, and five questions representing the ability to interpret scientific data and evidence. Each scientific literacy competency was measured using five indicators. This research analyzed students' answers based on the partitions in each indicator of scientific literacy competence. The analysis was used to obtain data on each indicator's percentage achievement in each of the competencies of scientific literacy. The percentage of 
achievement of scientific literacy indicators was then interpreted into five categories presented in Table 2.

Table 2

Category of Achievement Indicators ${ }^{28}$

\begin{tabular}{cc}
\hline Interval & Predicate \\
\hline $30-39$ & Failed \\
$40-55$ & Less than enough \\
\hline $56-65$ & Enough \\
\hline $66-79$ & Good \\
\hline $80-100$ & Excellent \\
\hline
\end{tabular}

The data were analyzed using descriptive analysis techniques and comparative statistical analysis with the Independent Sample T-Test in this study. Descriptive analysis was used to describe the results of students' scientific literacy abilities per item. In contrast, comparative statistical analysis in the form of an independent Sample T-Test was used to test whether there was a difference in scientific literacy ability between the two classes, which was used by comparing the two averages of two unrelated groups, and the results were calculated with the SPSS 20.00 program.

\section{RESULT AND DISCUSSION RESULT}

The analysis of the scientific literacy test scores showed that the average scientific literacy ability of students who received scientific literacy-assisted project learning was 82.67, while students who received lecture learning accompanied by experiments and used teaching materials commonly used in the lecture were 58.09. The ability of class A1 and A2 students in the three competencies of scientific literacy skills, namely explaining scientific phenomena, evaluating and designing scientific investigations, and interpreting scientific data and evidence, is presented in Figure 1.

${ }^{28}$ Suharsimi Arikunto, Dasar-Dasar Evaluasi Pendidikan (Jakarta: Bumi Aksara, 2013). 


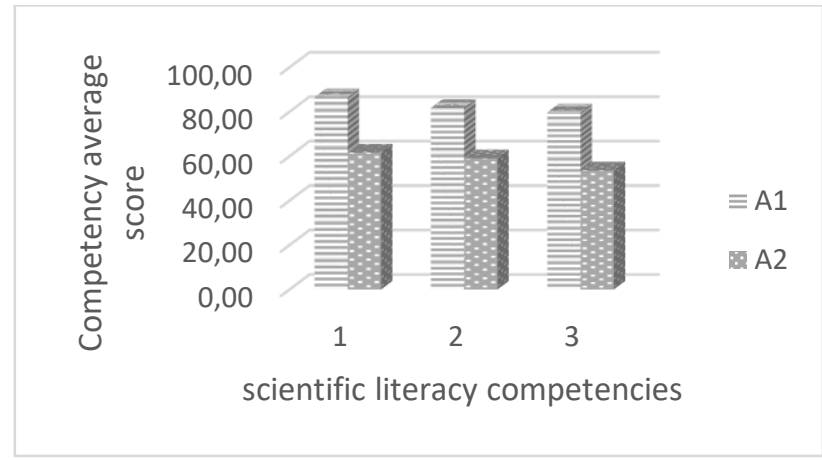

Figure 1

Comparison of the Abilities of Class A1 and A2

Students in Each Science Literacy Competency

Description: (1) explaining scientific phenomena; (2) evaluate and design scientific investigations; (3) interpret scientific data and evidence.

Based on Figure 1, it can be seen that the scientific literacy ability of class A1 students has a higher score in all three scientific literacy indicators than students of class A2, both in explaining scientific phenomena with an average score of 86.53 in A1 and 61.60 in $A 2$, evaluating and designing scientific investigation with an average score of 81.73 in A1 and 59.07 in A2, and interpreting scientific data and evidence with an average score of 79.73 in A1 and 53.60 in A2. Then, comparing the ability to explain scientific phenomena between class A1 students who receive STEM integrated project-based learning assisted by scientific literacy modules and class A2 students who receive lecture learning accompanied by experiments and use teaching materials commonly used in class is presented in class Figure 2.

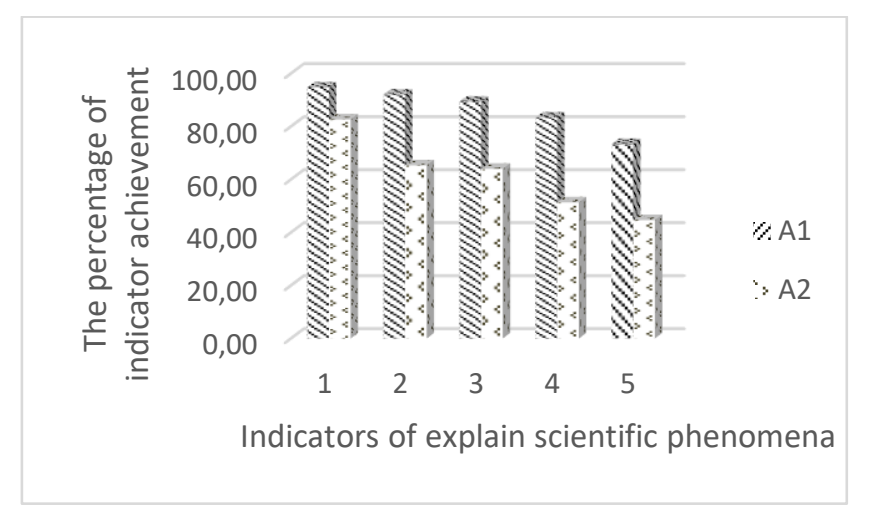

Figure 2

Comparison of Achievement Indicators of Ability to explain scientific phenomena for Class A1 and A2

Description: (1) remember and apply appropriate knowledge; (2) identify, use and produce a clear and representative model; (3) make and justify correct predictions; (4) provide a clear hypothesis; and (5) explain the potential implications of applying scientific knowledge to society. 
Figure 2 shows that the score of each question for class A1 students in the indicator "ability to explain scientific phenomena" is higher than the scores of students in class A2 with an average score of 86.53 for class A1 and 61.60 for class A2. Furthermore, comparing the ability to evaluate and design scientific investigations between class A1 students who received STEM integrated project learning assisted by scientific literacy modules and A2 class students who received lecture learning accompanied by experiments and using teaching materials commonly used in class is presented in Figure 3.

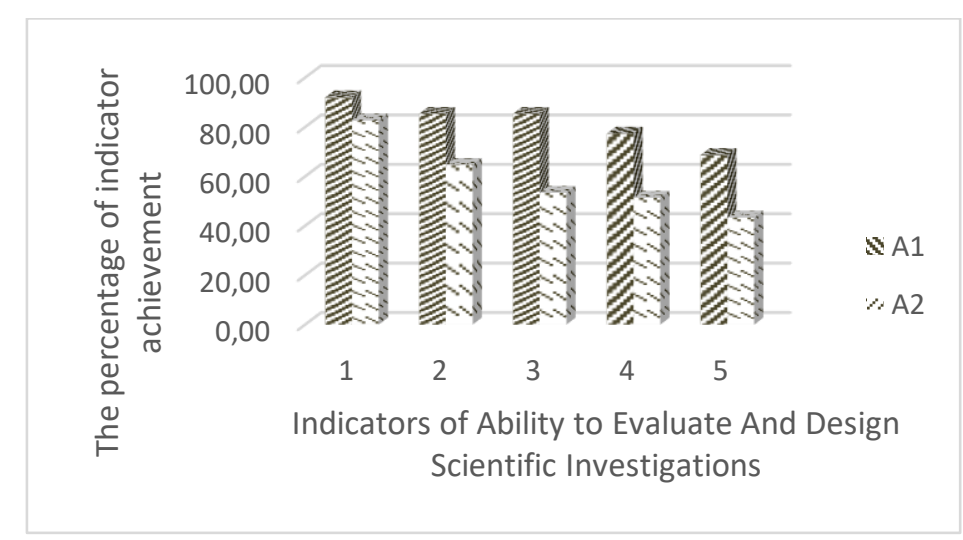

Figure 3

Comparison of Achievement of Ability to Evaluate And Design Scientific Investigations Class A1 and A2

Description: (1) identify questions for further exploration through scientific investigation; (2). distinguish questions that can be investigated scientifically; (3). propose ways of exploring a given question scientifically; (4). evaluate how to explore questions scientifically; and (5). explain and evaluate like a scientist ensuring the reliability and objectivity of the data.

Figure 3 shows that the score of each question for class A1 students in the indicator "evaluating and designing scientific investigations" is higher than the scores of students in class A2 with an average score of 81.73 for class A1 and 59.07 for class A2. Furthermore, comparing the ability to interpret scientific data and evidence between class A1 students who received STEM integrated project learning assisted by the scientific literacy module and class A2 students who received lecture learning accompanied by experiments and used teaching materials commonly used in class is presented in Figure 4. 


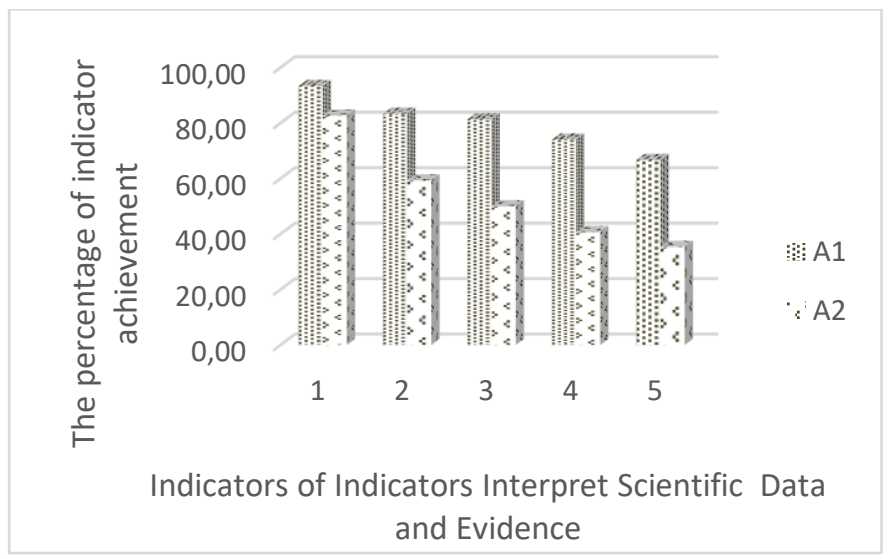

Figure 4.

Comparison of Achievement Indicators Interpret Scientific

Data and Evidence Class A1 and A2

Description: (1). transforming data from one form of representation to another; (2). analyze and interpret data and draw appropriate conclusions; (3). identify assumptions, evidence, and reasoning with related science; (4). distinguish between arguments based on scientific evidence, theory, and other considerations; and (5). evaluate scientific arguments and evidence from different sources.

Figure 4 shows that the score of each question for class A1 students in the indicator " interpreting scientific data and evidence " is higher than the scores of students in class A2 with an average score of 79.73 for class A1 and 53.60 for class A2.

Then, the normality test was carried out on the average results of the science literacy test scores in both class A1 and class A2, and it was found that the data were normally distributed with the $\mathrm{p}>.05$. Having done that, the Independent T-test was carried out from the average results of the science literacy test scores of students in class A1 and class A2. The results of the average score of scientific literacy ability can be seen in Table 3.

Table 3

Average Science Literacy Ability Test Results for Class A1 and Class A2

\begin{tabular}{lccccr}
\hline & Class & N & M & SD & \multicolumn{1}{c}{$\begin{array}{c}\text { Std. Error } \\
\text { Mean }\end{array}$} \\
\hline $\begin{array}{l}\text { Scientific } \\
\text { Literacy }\end{array}$ & A1 & 30 & 79.7333 & 6.96263 & 1.27120 \\
\cline { 2 - 6 } & A2 & 30 & 53.6000 & 4.88206 & .89134 \\
\hline
\end{tabular}

Table 3 shows that the results of the scientific literacy score for class A1 obtained a mean of 79.7333, and the results of the scientific literacy score for class A2 obtained a mean of 53.6000. Thus, from the average value, it can be concluded that there is a temporary difference between the scientific literacy skills of class A1 students who receive project learning assisted by the scientific literacy module and class A2 students 
who receive lecture learning accompanied by experiments and use teaching materials commonly used in class. Moreover, the results of the independent T-test can be seen in Table 4.

Table 4

Independent Sample T-Test of Scientific Literacy

\begin{tabular}{|c|c|c|c|c|c|}
\hline & & \multicolumn{2}{|c|}{$\begin{array}{l}\text { Levene's Test For } \\
\text { Equality Of Variances }\end{array}$} & \multicolumn{2}{|c|}{ T-Test For Equality Of Means } \\
\hline & & $\mathrm{F}$ & Sig. & $\mathrm{t}$ & df \\
\hline \multirow{3}{*}{$\begin{array}{l}\text { Scientific } \\
\text { Literacy }\end{array}$} & Equal & & & & \\
\hline & $\begin{array}{l}\text { Variances } \\
\text { Assumed }\end{array}$ & 3.397 & .070 & 16.832 & 58 \\
\hline & $\begin{array}{l}\text { Equal } \\
\text { Variances } \\
\text { Not } \\
\text { Assumed }\end{array}$ & & & 16.832 & 51.965 \\
\hline
\end{tabular}

It can be seen from Table 4 that from the results of the $t$-test that $t_{\text {count }}$ (Equal Variance Assumed) is 16.832 while t-table is at a significance level of $5 \%$ for df 58 , then the $t_{\text {table }}$ value for the 5\% significance level is 2.001 . This finding means that $t_{\text {count }}>t_{\text {table }}$ $(16.832>2.001)$ then $\mathrm{Ha}$ is accepted. From this comparison, it can be concluded that there is a significant difference between the literacy abilities of class A1 students who receive STEM-based integrated project-based learning and class A2 students who receive lecture learning by experiment.

\section{DISCUSSION}

Science literacy is one of the goals of science education. ${ }^{29}$ The test analysis of science literacy ability showed that class A1 students who received STEM integrated project-based learning assisted by modules containing scientific literacy had higher literacy skills than students in class A2 who received lecture learning accompanied by experiments and used teaching materials commonly used in lectures. This difference in literacy abilities can be caused because class A1 students use teaching materials that contain scientific literacy so that their scientific literacy skills can develop better than class A2 students who do not use modules containing scientific literacy. The research finding is following the opinion of $\mathrm{Dani}^{30}$, who states that the quality of teaching materials

\footnotetext{
${ }^{29}$ Jack Holbrook and Miia Rannikmae, “The Meaning of Scientific Literacy," International Journal of Environmental and Science Education 4, no. 3 (July 2009): 275-88, https://eric.ed.gov/?id=ej884397.

${ }^{30}$ Danielle Dani, "Scientific Literacy and Purposes for Teaching Science: A Case Study of Lebanese Private School Teachers," International Journal of Environmental and Science Education 4, no. 3 (July
} 
used by teachers or lecturers plays a vital role in providing learning experiences that contain scientific literacy.

The results of this study are also following research conducted by Sugianto ${ }^{31}$, which shows that the use of teaching materials with scientific literacy in the learning process can improve students' scientific literacy skills. The difference in scientific literacy abilities of the two research classes can also be caused by the first-class students getting integrated STEM project-based learning that involves students in real-life problemsolving activities and involves students in investigations. The involvement of students in these two activities allows students to apply the scientific concepts they have in real life to encourage students' scientific literacy skills to develop better than those who do not receive project-based learning. This finding is consistent with the results of research by McCright $^{32}$, which shows that students' scientific literacy skills can be improved through the application of project-based inquiry learning. In addition, the integration of STEM in project-based learning in lectures can encourage students to design, develop and utilize technology, hone cognitive, become manipulative and affective, and apply knowledge. ${ }^{33}$ This statement follows with the Permanasari ${ }^{34}$ who states that STEM can increase the mastery of knowledge to solve problems through scientific literacy and encourage students to create something new.

The scientific literacy abilities of students measured in this study include three competencies, namely the ability to explain scientific phenomena, evaluate and design scientific investigations, and interpret scientific data and evidence. This study indicates that students who receive STEM integrated project learning assisted by modules with scientific literacy in interpreting data and scientific evidence are lower than the other two scientific literacy competencies, as shown in Figure 1. The study results also show that students who receive lecture learning accompanied by Experiments have a lower ability

2009): 289-99, https://eric.ed.gov/?id=EJ884398.

${ }^{31}$ Sugianto, "Pengembangan Bahan Ajar Berbasis Literasi Sains Materi Suhu Dan Kalor."

32 Aaron M. McCright, "Enhancing Students' Scientific and Quantitative Literacies through an Inquiry-Based Learning Project on Climate Change," Journal of the Scholarship of Teaching and Learning 12, no. 4 (December 2012): 86-101, https://eric.ed.gov/?id=EJ992129.

33 Vikram Kapila and Magued Iskander, "Lessons Learned from Conducting a K-12 Project to Revitalize Achievement by Using Instrumentation in Science Education," Journal of STEM Education 15, no. 1 (April 1, 2014), https://www.learntechlib.org/p/148286/.

34 Anna Permanasari, "STEM Education: Inovasi Dalam Pembelajaran Sains,” Prosiding SNPS (Seminar Nasional Pendidikan Sains) 3, no. $0 \quad$ (2016): 23-34, https://jurnal.fkip.uns.ac.id/index.php/snps/article/view/9810. 
to evaluate and design scientific investigations than the other two scientific literacy competencies. The highest ability of students' scientific literacy in this study was to explain scientific phenomena. This finding follows the results of a study by Tjalla ${ }^{35}$, which shows that the highest competence in students' scientific literacy in Indonesia is in the ability to explain scientific phenomena, while the lowest is in the ability to use scientific facts.

Five indicators measure the ability of students to explain scientific phenomena in this study. Figure 2 shows that the achievement of indicators (1), (2), (3), and (4) in the ability to explain scientific phenomena is relatively high compared to indicators (5). Students who obtained PjBL integrated STEM assisted by modules with scientific literacy showed a percentage of achievement of $94 \%$ on indicators of remembering and applying appropriate knowledge and $92 \%$ on indicators of identifying, using, and producing clear and representative models. This percentage was higher than students who received lecture learning accompanied by experiments and used teaching materials commonly used in class, which showed that indicators (1) and (2) were $82 \%$ and $65 \%$, respectively. Students who obtain STEM integrated PjBL assisted by modules with scientific literacy have been able to remember and apply appropriate knowledge properly and sufficiently identify, use, and produce clear and representative models. Students who receive lecture learning accompanied by experiments and use teaching materials commonly used in class are sufficiently capable of remembering and applying appropriate knowledge but have not identified, used, and produced clear and representative models, as shown in Figure 2. Research results also show that both groups of students can explain the potential implications of applying scientific knowledge to society.

The profile of students' abilities in explaining scientific phenomena shows that the highest ability that can be achieved by both students who receive project learning and those who receive lecture learning accompanied by experiments is the ability to remember and apply appropriate knowledge. This phenomenon happens because this ability is the lowest in achieving scientific literacy skills. Students in class A1 are better at remembering and applying appropriate knowledge than students in class A2. The cause

35 Awaluddin Tjalla, "Potret Mutu Pendidikan Indonesia Ditinjau Dari Hasil-Hasil Studi Internasional” (Temu Ilmiah Nasional Guru II: Membangun Profesionalitas Insan Pendidikan Yang Berkarakter dan Berbasis Budaya, Tangerang Selatan, 2010), http://repository.ut.ac.id/2609/. 
is that grade A1 student better understand the concept, as conveyed by Hixson ${ }^{36}$ and Sastrika $^{37}$, who stated that project-based learning could improve understanding of concepts and learning outcomes.

The ability of students to evaluate and design scientific investigations in this study is measured based on five indicators. The achievement of competence in evaluating and designing scientific investigations in class A1 is relatively high on indicators (1), (2), and (3) compared to indicators (4) and (5), as shown in Figure 3. Figure 3 shows that students' abilities STEM integrated PjBL is assisted by modules containing scientific literacy in evaluating and designing scientific investigations higher than students who do not receive project learning. This finding is following the opinion of Khalek \& $\mathrm{Lee}^{38}$, who states that project learning encourages students to carry out constructive investigations that involve planning, decision making, problem-solving, and discovery. According to $\mathrm{Uziak}^{39}$, project-based learning encourages students to be involved in various investigative and decision-making activities based on their knowledge.

The ability of students to interpret data and scientific evidence in this study is measured by five indicators. Figure 4 shows that class A1 students are quite capable of transforming data from one form of representation to another and can analyze and interpret data, including drawing appropriate conclusions. Class A2 students can transform data from one form of representation to another but have not analyzed and interpreted data or draw appropriate conclusions. This finding shows that grade A1 students are better at interpreting scientific data and evidence than grade A2 students. In addition, PjBL requires students to demonstrate their knowledge by producing products and presenting them in front of their peers. This research finding is in line with the opinion

${ }^{36}$ Nate K. Hixson, Jason Ravitz, and Andy Whisman, Extended Professional Development in Project-Based Learning: Impacts on 21st Century Skills Teaching and Student Achievement, West Virginia Department of Education (West Virginia Department of Education, 2012), https://eric.ed.gov/?id=ED565466.

${ }^{37}$ Ida Ayu Kade Sastrika, I Wayan Sadia, and I Wayan Muderawan, "Pengaruh Model Pembelajaran Berbasis Proyek Terhadap Pemahaman Konsep Kimia Dan Keterampilan Berpikir Kritis,” E-Journal Program Pascasarjana Universitas Pendidikan Ganesha 3 (2013): 1-10, http://ejournalpasca.undiksha.ac.id/index.php/jurnal_ipa/article/download/799/584.

${ }^{38}$ AK Aiedah and KC Lee, “Application Of Project-Based Learning In Students' Engagement In Malaysian Studies And English Language,” Journal of Interdisciplinary Research in Education (JIRE) 2, no. 1 (2012): 37-46, https://university2.taylors.edu.my/jire/downloads/vol2_03.pdf.

39 Jacek Uziak, "A Project-Based Learning Approach In An Engineering Curriculum," Global Journal of Engineering Education 18, no. 2 (2016): 119-23, http://wiete.com.au/journals/GJEE/Publish/vol18no2/12-Uziak-J.pdf. 
of Robinson ${ }^{40}$, who states that students in project learning are allowed to use their knowledge in creating products that are then presented. Students in project learning can produce products after conducting investigations and use their investigations to solve real-life problems. According to Roessingh \& Chambers $^{41}$ students in the project learning is given tasks to solve real problems to encourage students to develop high-level reflection skills and higher-order thinking skills.

\section{CONCLUSION}

The scientific literacy abilities of students who received STEM integrated project learning assisted by modules with scientific literacy were better, with an average test result of 82 compared to students who received lecture learning accompanied by experiments and used teaching materials commonly used in lecture with an average test result of 58. Besides, Independent T-Test showed a significant difference between the literacy abilities of class A1 students and class A2 students. The highest class A1 students' scientific literacy is in the ability to explain scientific phenomena, and the lowest is in the ability to interpret data and scientific evidence. The scientific literacy ability of students who get lecture learning accompanied by experiments is the highest in the ability to explain scientific phenomena, and the lowest is in the ability to evaluate and design scientific investigations. The results of this research indicate that the ability of students to interpret data and scientific evidence in STEM integrated project-based learning assisted by modules with scientific literacy is still low, so further research is needed to make modifications to the PjBL integrated STEM model assisted by this module to be more effective in improving student abilities in interpreting scientific data and evidence.

\section{ACKNOWLEDGMENTS}

The researcher would like to say thank you to everyone who has contributed to the preparation, arrangement, and proofreading of this article. This research was conducted for Elementary Teacher Education Program at IKIP Siliwangi Bandung, Indonesia.

${ }^{40}$ Jill K. Robinson, "Project-Based Learning: Improving Student Engagement and Performance in the Laboratory," Analytical and Bioanalytical Chemistry, 2013, https://doi.org/10.1007/s00216-012-6473$\mathrm{x}$.

41 Hetty Roessingh and Wendy Chambers, "Project-Based Learning and Pedagogy in Teacher Preparation: Staking out the Theoretical Mid-Ground," International Journal of Teaching and Learning in Higher Education 23, no. 1 (2011): 60-71, https://eric.ed.gov/?id=EJ938579. 


\section{DECLARATION OF CONFLICTING INTERESTS}

The author/s declared no potential conflicts of interest with respect to the research, authorship, and/or publication of this article.

\section{FUNDING}

This research was funded by the researcher's independent fund. But researcher would like to say thank you to IKIP Siliwangi which has helped a lot in giving permission to take samples of research subjects.

\section{ORCID iD}

Duhita Savira Wardani iD https://orcid.org/0000-0003-1286-1687

\section{REFERENCES}

Afriana, Jaka, Anna Permanasari, and Any Fitriani. "Penerapan Project Based Learning Terintegrasi STEM Untuk Meningkatkan Literasi Sains Siswa Ditinjau Dari Gender." Jurnal Inovasi Pendidikan IPA 2, no. 2 (2016): 202. https://doi.org/10.21831/jipi.v2i2.8561.

Aiedah, AK, and KC Lee. "Application Of Project-Based Learning In Students' Engagement In Malaysian Studies And English Language." Journal of Interdisciplinary Research in Education (JIRE) 2, no. 1 (2012): 37-46. https://university2.taylors.edu.my/jire/downloads/vol2_03.pdf.

Ardiyanti, Y., S. Suyanto, and I. G.P. Suryadarma. "The Role of Students Science Literacy in Indonesia." In Journal of Physics: Conference Series, 2019. https://doi.org/10.1088/1742-6596/1321/3/032085.

Arikunto, Suharsimi. Dasar-Dasar Evaluasi Pendidikan. Jakarta: Bumi Aksara, 2013.

Baran, Medine, and Abdulkadir Maskan. "The Effect Of Project-Based Learning On PreService Physics Teachers Electrostatic Achievements." Cypriot Journal of Educational Sciences 5, no. 4 (2011): 243-57. https://archives.unpub.eu/index.php/cjes/article/viewArticle/117.

Capraro, Robert M., Mary Margaret Capraro, and James R. Morgan. STEM Project-Based Learning an Integrated Science, Technology, Engineering, and Mathematics (STEM) Approach. STEM Project-Based Learning an Integrated Science, Technology, Engineering, and Mathematics (STEM) Approach, 2013. https://doi.org/10.1007/978-94-6209-143-6.

Cook, Kristin, Gayle Buck, and Meredith Park Rogers. "Preparing Biology Teachers To Teach Evolution In A Project-Based Approach." Science Educator 21, no. 2 (2012):

https://www.nsela.org/assets/Preparing\%20Biology\%20Teachers\%20to\%20Tea ch\%20Evolution\%20in\%20a\%20Project-Based\%20Approach.pdf.

Dani, Danielle. "Scientific Literacy and Purposes for Teaching Science: A Case Study of 
Lebanese Private School Teachers." International Journal of Environmental and Science Education 4, no. 3 (July 2009): 289-99. https://eric.ed.gov/?id=EJ884398.

Ergül, N. Remziye, and Elif Keskin Kargın. "The Effect of Project Based Learning on Students' Science Success.” Procedia - Social and Behavioral Sciences 136 (2014): 537-41. https://doi.org/10.1016/j.sbspro.2014.05.371.

Hixson, Nate K., Jason Ravitz, and Andy Whisman. Extended Professional Development in Project-Based Learning: Impacts on 21st Century Skills Teaching and Student Achievement. West Virginia Department of Education. West Virginia Department of Education, 2012. https://eric.ed.gov/?id=ED565466.

Holbrook, Jack, and Miia Rannikmae. "The Meaning of Scientific Literacy." International Journal of Environmental and Science Education 4, no. 3 (July 2009): 275-88. https://eric.ed.gov/?id=ej884397.

Jufrida, Jufrida, Fibrika Rahmat Basuki, Wawan Kurniawan, Miko Danu Pangestu, and Olva Fitaloka. "Scientific Literacy and Science Learning Achievement at Junior High School." International Journal of Evaluation and Research in Education, 2019. https://doi.org/10.11591/ijere.v8i4.20312.

Kapila, Vikram, and Magued Iskander. "Lessons Learned from Conducting a K-12 Project to Revitalize Achievement by Using Instrumentation in Science Education." Journal of STEM Education 15, no. 1 (April 1, 2014). https://www.learntechlib.org/p/148286/.

K1lınç, Ahmet. "Can Project-Based Learning Close The Gap? Turkish Student Teachers and Proenvironmental Behaviours," 2010. http://openaccess.ahievran.edu.tr/xmlui/handle/20.500.12513/181.

Kurnia, Feni, . Zulherman, and Apit Fathurohman. "Analisis Bahan Ajar Fisika Sma Kelas XI Di Kecamatan Indralaya Utara Berdasarkan Kategori Literasi Sains.” Jurnal Inovasi Dan Pembelajaran Fisika, 2014. https://doi.org/10.36706/jipf.v1i1.1263.

Lutfi, Lutfi, Andi Asmawati Azis, and Ismail Ismail. "Pengaruh Project Based Learning Terintegrasi Stem Terhadap Literasi Sains, Kreativitas dan Hasil Belajar Peserta Didik." Seminar Nasional Biologi, no. 0 (October 17, 2018). https://ojs.unm.ac.id/semnasbio/article/view/6984.

Maghfiroh, Nuril, Herawati Susilo, and Abdul Gofur. "Pengaruh Project Based Learning Terhadap Keterampilan Proses Sains Siswa Kelas X SMA Negeri Sidoarjo." Jurnal Pendidikan: Teori, Penelitian, dan Pengembangan 1, no. 8 (August 1, 2016): 1588-93. https://doi.org/10.17977/jp.v1i8.6673.

McCright, Aaron M. “Enhancing Students' Scientific and Quantitative Literacies through an Inquiry-Based Learning Project on Climate Change." Journal of the Scholarship of Teaching and Learning 12, no. 4 (December 2012): 86-101. https://eric.ed.gov/?id=EJ992129.

OECD. "PISA 2015 Draft Scince Framework March 2013," 2013.

OECD. "PISA 2018 Results in Focus.Https://Www.Oecd.Org/Pisa/Pisa-2018-Results-inFocus.Pdf," 2018. 
Özer, Dilek Zeren, and Muhlis Özkan. "Proje Tabanlı Öğretimin Fen Bilgisi Öğretmen Adaylarının Bilimsel Süreç Becerileri Üzerine Etkisi.” Journal of Turkish Science Education 9, no. 3 (September 15, 2012): 119-30. http://www.tused.org/index.php/tused/article/view/443.

Panasan, Mookdaporn, Prasart Nuangchalerm, and Amphoe Muang. "Learning Outcomes of Project-Based and Inquiry-Based Learning Activities Department of Curriculum and Instruction , Faculty of Education , Mahasarakham University , Mahasarakham 44000 Thailand.” Journal of Social Sciences 6, no. 2 (2010): 25255. https://files.eric.ed.gov/fulltext/ED509723.pdf.

Permanasari, Anna. "STEM Education: Inovasi Dalam Pembelajaran Sains." Prosiding SNPS (Seminar Nasional Pendidikan Sains) 3, no. 0 (2016): 23-34. https://jurnal.fkip.uns.ac.id/index.php/snps/article/view/9810.

Robinson, Jill K. "Project-Based Learning: Improving Student Engagement and Performance in the Laboratory." Analytical and Bioanalytical Chemistry, 2013. https://doi.org/10.1007/s00216-012-6473-x.

Roessingh, Hetty, and Wendy Chambers. "Project-Based Learning and Pedagogy in Teacher Preparation: Staking out the Theoretical Mid-Ground." International Journal of Teaching and Learning in Higher Education 23, no. 1 (2011): 60-71. https://eric.ed.gov/?id=EJ938579.

Sari, Desi Novita Anggun, Ani Rusilowati, and Murbangun Nuswowati. "Pengaruh Pembelajaran Berbasis Proyek Terhadap Kemampuan Literasi Sains Siswa." PSEJ (Pancasakti Science Education Journal) 2, no. 2 (2017): 114. https://doi.org/10.24905/psej.v2i2.741.

Sastrika, Ida Ayu Kade, I Wayan Sadia, and I Wayan Muderawan. "Pengaruh Model Pembelajaran Berbasis Proyek Terhadap Pemahaman Konsep Kimia Dan Keterampilan Berpikir Kritis.” E-Journal Program Pascasarjana Universitas Pendidikan Ganesha 3 (2013): 1-10. http://ejournalpasca.undiksha.ac.id/index.php/jurnal_ipa/article/download/799/584.

Stohlmann, Micah, Tamara Moore, and Gillian Roehrig. "Considerations for Teaching Integrated STEM Education." Journal of Pre-College Engineering Education Research, 2012. https://doi.org/10.5703/1288284314653.

Sugianto, A. D. Paramita, A. Rusilowati. "Pengembangan Bahan Ajar Berbasis Literasi Sains Materi Suhu Dan Kalor." Phenomenon: Jurnal Pendidikan MIPA, 2017. https://doi.org/10.21580/phen.2017.7.1.1495.

Susilawati, Endang, and Agustinasari. "Implementasi Project Based Learning Berbasis Potensi Lokal Untuk Meningkatkan Keterampilan Proses Sains Mahasiswa Pendidikan Fisika." Jurnal Pendidikan MIPA 7, no. 1 (June 30, 2017): 43-47. http://www.ejournal.tsb.ac.id/index.php/jpm/article/view/19.

Tjalla, Awaluddin. "Potret Mutu Pendidikan Indonesia Ditinjau Dari Hasil-Hasil Studi Internasional." Tangerang Selatan, 2010. http://repository.ut.ac.id/2609/.

Toolin, Regina E. "Striking a Balance Between Innovation and Standards: A Study of Teachers Implementing Project-Based Approaches to Teaching Science." Journal of Science Education and Technology 13, no. 2 (2004): 179-87. 
https://doi.org/10.1023/b:jost.0000031257.37930.89.

Turiman, Punia, Jizah Omar, Adzliana Mohd Daud, and Kamisah Osman. "Fostering the 21st Century Skills through Scientific Literacy and Science Process Skills." Procedia - Social and Behavioral Sciences, 2012. https://doi.org/10.1016/j.sbspro.2012.09.253.

Udompong, Lertporn, and Suwimon Wongwanich. "Diagnosis of the Scientific Literacy Characteristics of Primary Students." Procedia - Social and Behavioral Sciences, 2014. https://doi.org/10.1016/j.sbspro.2014.01.1079.

Uziak, Jacek. "A Project-Based Learning Approach In An Engineering Curriculum." Global Journal of Engineering Education 18, no. 2 (2016): 119-23. http://wiete.com.au/journals/GJEE/Publish/vol18no2/12-Uziak-J.pdf.

Wardani, Duhita Savira, Muhammad Rizal Fauzi, Ruwaida Zafira, and Dian Kurniawati. "Creating Props: Improving Writing Skills of Teaching Materials of Elementary Teacher Education Students through Project-Based Learning Model.” Mimbar Sekolah Dasar 7, no. 2 (2020): 216-34. https://doi.org/10.17509/mimbarsd.v7i2.26334.

Yuliati, Yuyu. "Literasi Sains Dalam Pembelajaran IPA.” Jurnal Cakrawala Pendas 3, no. 2 (2017): 21-28. https://doi.org/10.31949/jcp.v3i2.592 
This page is intentionally left blank 